Divine and Mortal Motivation : On the Movement of Life in Aristotle and Heidegger

\title{
Backman, Jussi
}

2005

Backman , J 2005 , ' Divine and Mortal Motivation : On the Movement of Life in Aristotle and

Heidegger ' , Continental Philosophy Review , vol. 38 , no. 3-4 , pp. 241-261 . https://doi.org/10.1007/s11007-006-90

http://hdl.handle.net/10138/157915

https://doi.org/10.1007/s11007-006-9007-4

acceptedVersion

Downloaded from Helda, University of Helsinki institutional repository.

This is an electronic reprint of the original article.

This reprint may differ from the original in pagination and typographic detail.

Please cite the original version. 
This is the accepted manuscript of the article published in Continental Philosophy Review 38/3 (2005): 241-261. The final publication is available at Springer via http://dx.doi.org/10.1007/s11007-006-9007-4

DIVINE AND MORTAL MOTIVATION:

ON THE MOVEMENT OF LIFE IN ARISTOTLE AND HEIDEGGER

\author{
JUSSI BACKMAN
}

\title{
Abstract
}

The paper discusses Heidegger's early notion of the "movedness of life" (Lebensbewegtheit) and its intimate connection with Aristotle's concept of movement (kinessis). Heidegger's aim in the period of Being and Time was to "overcome" the Greek ideal of being as ousia constant and complete presence and availability - by showing that the background for all meaningful presence is Dasein, the ecstatically temporal context of human being. Life as the event of finitude is characterized by an essential lack and incompleteness, and the living present therefore gains meaning only in relation to a horizon of un-presence and unavailability. Whereas the "theological" culmination of Aristotle's Nicomachean Ethics finds the supreme fulfillment of human life in the semi-divine self-immanence and self-sufficiency of the bios theōrētikos, a radical Heideggerian interpretation of kinēsis may permit us to find in Aristotle the fundamental structures of mortal living as self-transcendent movement. 
Vita maxime in motu manifestatur

Life is most manifest in movement.

(St. Thomas Aquinas: Summa contra gentiles, IV, 20.)

We know that in the early 1920s, Heidegger frequently referred to his main project - the background for his famed lecture courses in Freiburg and Marburg - as "Phenomenological Interpretations in Connection with Aristotle" (Phänomenologische Interpretationen zu Aristoteles). Although at some point around 1924, the Aristotle project was definitely supplanted by, or rather transformed into, the Being and Time project ${ }^{1}$, it is clear that Heidegger never abandoned the essential insights of his Aristotle readings but rather incorporated them into Being and Time and his later works. Most scholars now agree that Heidegger's encounter with Aristotle was decisive for the initial orientation of his "path of thinking." Thomas Sheehan, notably, has suggested that understanding Heidegger's reappropriation of the intertwined Aristotelian concepts dynamis (capacity, potentiality) and kinēsis (movement, process) would, in particular, permit us to approach the sole unifying "matter" (Sache) of Heidegger's thought as a whole - the matter which Heidegger from the 1930s onward referred to as Ereignis, the event or "taking-place" of meaningfulness. ${ }^{2}$

Heidegger's "Natorp account"3 from 1922 shows that this matter was present already in the very earliest phase of Heidegger's career. Here, Heidegger sets forth precisely the task of understanding Aristotle's ontology of movement as well as the connection of this ontology with Aristotle's understanding of "the movedness of living" (Lebensbewegtheit) ${ }^{4}$. "[. . . ] the ontological structure of human being is understood on the basis of an ontology of beings in the how of a particular kind of movedness [Bewegtheit] and on the basis of the ontological radicalization of the idea of this kind of movedness." ${ }^{5}$ In what follows, I will discuss precisely this phenomenon, which can be seen as the very focal point of Heidegger's 
interpretation of Aristotle: the movement, mobility or "motivation" of living. Pursuing the path indicated by Sheehan, I will try to show how Heidegger "reads Aristotle against Aristotle" in trying to find in the concept of kinessis ${ }^{6}$ a formulation of the ontological structure of human life that is more original and more appropriate (eigentlich) - phenomenologically more adequate to the phenomenon itself - than the one found in Aristotle's specific reflection on the final ends and the supreme essence of living. Whereas Aristotle himself found the essence of human life precisely in the attainment of a certain degree of immortality and permanent presence, a radical reappropriation of the Aristotelian concept of kinessis may indeed permit us to call into question this "theological" dimension of Aristotle's ethics and to think of life as the foundational event of mortality and finitude.

\section{Being-in-possession and being-out-after}

What is the most fundamental principle of Aristotle's philosophy? Heidegger's answer to this question is well-known: this principle is expressed by the Greek word ousia, literally "beingness," which Heidegger mostly interprets as Anwesenheit, "presence," "being-inpossession," or Vorhandenheit, "availability," "being-at-hand."7 Ousia indicates, according to Heidegger, nothing less than the basic and initial meaning of being for Aristotle. It is a principle which Aristotle explicates and articulates in such fundamental investigations as Books Zeta and Eta of the Metaphysics and the treatise on the Categories. Ousia means the "substantial" way of being, the first, "underlying" (Greek hypokeimenon, Latin substantia) category of being of which the other categories are predicated: independence of other beings, self-identity, unity, uniformity, fundamentality, indivisibility and permanence. ${ }^{8}$ All of these, Heidegger says, are basically aspects of the one and same fundamental character of the beingness of beings - constant presence (beständige Anwesenheit). This initial grasp of the comprehensive sense of being has, in the course of the unfolding of the Western tradition of 
thought, become so self-evident that it is no longer even a theme for investigation. In the Heideggerian schema, it was the epochal unfolding of different implicit aspects of ousia that produced the medieval theology of the Christian God as the ens realissimum, as the most real and substantial (most constantly present) of beings; the Cartesian interpretation of the cognizing I-subject (cogito) as indubitably certain self-presence; the Hegelian interpretation of history as an unfolding of the absolute presence-to-itself of subjectivity; and, as its final phase, Nietzsche's thought of the "will to power" as the urge of the living subject to secure its self-presence through self-assertion. ${ }^{9}$

The Heideggerian interpretation of ousia is perhaps best illustrated by Heidegger's counterexample to this principle: factical life in its motional and motivational way of being. As analyzed by Heidegger, the human Dasein, in its most proper mode (Eigentlichkeit), simply does not present itself as a stable, unified, complete, finished, self-sufficient and perfect presence-in-itself-and-to-itself. Instead, human being has its very own way of taking place, characterized by Heidegger in Being and Time as "ek-sistence" or "ek-static temporality,"10 expressions that literally mean "standing outside"; human being is essentially "outside itself," that is, outside and beyond a purely present now of self-grasping, selfidentity and self-coincidence. The manner in which Dasein is is captured by the expression care (Sorge), which is explicated as "being-ahead-of-itself-already-in-(the-world) as beingalongside (beings encountered within-the-world)". ${ }^{11}$ This complex structure is then elucidated in temporal terms in Part I, Division 2 of Being and Time, "Dasein and Temporality," especially in Section 65, "Temporality as the ontological meaning of care." Human being is essentially "ahead of itself," futural - that is, life is lived ahead, life always gains present sense or meaning from the future (Zukunft), from the possibilities and goals at which it is oriented, and sees its past, its already-having-lived (Gewesenheit), as meaningful through the possibilities it opens up for the future. Human being is essentially "already in the 
world," historical - that is, any meaningful present situation of life is meaningful on the basis of a de facto background, an "always already" past, a tradition which generates and delimits in advance one's own factical possibilities. Only thus can human being be "alongside beings" - that is, encounter beings as meaningfully present in a lived situation (Gegenwart). In the Natorp account, Heidegger has a very apt expression for this "self-external" character: beingalive is essentially Aussein auf etwas, "being out for something," "being out after something." 12

In other words, human being is attracted, moved - "motivated" in the literal sense of the word - outwards, into exteriority, and this outward motivation then constitutes the transcendent character of living. However, there is no prior immanent or interior self or underlying subject to be transcended, nor is human being motivated by anything exterior to itself. Human being as such is its own outward motivation: it is a movement into its own unrealized possibilities, and these possibilities are precisely what life itself is all about, the source of its selfhood. ${ }^{13}$ What human being as a whole aims at in its movement is precisely itself as a possibility. In Heidegger's formulation: "Dasein exists for the sake of a can-be [Seinkönnen] of itself.",14

Precisely because of this constitutive self-motivated and self-transcendent mobility, life cannot be grasped radically and adequately through the category of ousia. Human being is never wholly encapsulated within a self-sufficient present moment or a now, but is always outside and beyond the present, which, in fact, can be meaningfully present only in relation to what is precisely non-present: that-toward-which (future, possibility) and that-out-ofwhich (past, history) life is being lived. There is no immanence without transcendence. Human being is not the state of being-alive - it is the event, the coming-to-pass of living. As long as life is life, it cannot be "finished with" - life does not attain the most perfect form of actuality, entelecheia, "having-reached-completeness," which Heidegger interprets as the 
simple resting of a being in its most perfect form of presence in itself and as itself, its eidos. ${ }^{15}$ On the contrary, living is essentially characterized by perpetual unrest (Unruhe). ${ }^{16}$

Yet even though human being is always still "on the way" to itself, living one's life is not simply a process of production, Greek poiēsis, which would be completed upon reaching some final goal or end, telos, lying outside the process itself. Human being is not unfinished in the sense that a building under construction is unfinished. In any given situation of life, the unfinished project I am carrying on with is my life itself. Human being in its unfinished fullness is always already "going on," "in full swing" - energeia, "already operative"17. Life is simply this being-on-the-way to itself. ${ }^{18}$

In this sense, the movement of human being fits the Aristotelian definition of praxis as pure activity that always already contains its own telos and goes on for its own sake. ${ }^{19}$ Yet for Aristotle, praxis in the most authentic sense is a self-immanent motion, a movement entirely devoid of exteriority or incompleteness - that is, rest - whereas life, in any given situation, also has unrealized possibilities and potentialities, Greek dynameis. There is always some "unfinished business" in life. As a self-transcendent and outwards-motivated movement, human being as a whole does not have the self-immanence of praxis. Human being is actualized precisely as long as it has purely potential, unrealized possibilities. When there are no more open possibilities, life is indeed "finished," but in the sense that it is "over and done with." ${ }^{20}$ The ecstatic temporality of Dasein thus transgresses and eludes the fundamental classification of activities under poiessis and praxis: it is a movement that has the transcendence of poiessis and yet does not attain any external goal but, like praxis, takes place for its own sake. ${ }^{21}$ This paradoxical way of being - being fully realized precisely in not-yetbeing finished - is obviously at odds with the sense of being governing Western philosophy, ousia. 


\section{A life of one's own}

How, then, can the question of the essence of human being as life be addressed from within the framework of ousia? Aristotle's "theological" answer in Book X of the Nicomachean Ethics to the question concerning the final end, the telos, of human life is one of the most decisive moves in the development of Western thought. Here Aristotle's ethical search for the most appropriate human living ends in the conclusion that its fullest realization takes place in the "theoretical" way of life, bios theōrētikos. ${ }^{22}$ Theōria or theōrein means simply the "disinterested," non-instrumental beholding of reality - specifically, of the fundamental and necessary, eternal structures of reality. In the activity of theōrein, the living soul ceases to be "out for something," as it constantly is in ordinary life, and concentrates on beholding the permanently and fully present purely for the sake of this presence itself, without reference to any non-actualized possibilities or goals. This makes theōria the most powerful (kratistē), the most contiguous (synechestatē), the most pleasant (hèdistē) and the most self-sufficient and independent (autarkestatos) - all in all, the most present-to-itself and the most fully actualized - form of living one's life. ${ }^{23}$ Theōria is not an opposite of praxis, of human activity concerned about itself, on the contrary, it is the perfection of praxis: a movement of life that is motivated purely by the full presence of the fully present. ${ }^{24}$ In a certain sense, Aristotle says, this form of living is an athanatizein, "being-immortal" - it entails a certain

release from human mortality and finitude. ${ }^{25}$ As such, theoretical life is also the most "divine" (theion) way of life possible for the human being. ${ }^{26}$

Heidegger emphasizes that in Aristotle, "divine" is to be understood strictly as an ontological term meaning simply "immortal," "self-sufficient" and "most being." 27 In Book Lambda of the Metaphysics, divinity, the divine way of being - here understood as an ideal that human life may at best approach but never, because of its essential imperfection, permanently attain - is described as having its essence in nous, insight or apprehension, i.e., 
in the pure, immediate, non-propositional, non-discursive, non-temporal and non-analyzable grasping of indivisible and permanent truths, and particularly in noēsis noēseōs, in the selfreferential divine apprehension apprehending purely itself. The perfection of God entails active awareness, and in order to be perfect, this can only be God's self-awareness of his own perfect activity. ${ }^{28}$ God is simply the most perfect presence-in-itself-and-to-itself, without any reference outside or beyond itself. "Indeed, we maintain the divinity [theos] to be a constant and most excellent living being, so that in the divinity a contiguous and constant living [zōe $]$ and span of being are present. For this is precisely what the divinity is." 29

Aristotle thus sees the supreme and essential possibility of life in a certain freeing oneself from mortality and intentionality, from being "out for something." One must, in a way, "cease to exist" in order to realize one's most supreme possibilities as a human being which, at the same time, means approaching divinity. Aristotle thus draws the full "ethical" conclusions from the initial identification of beingness with constant presence. What he envisages as the most authentic and perfect human life is already indicated in the reputed words of Anaxagoras, cited in a fragment supposedly belonging to Aristotle's lost Protrepticus:

And when somebody asked Anaxagoras for what end one would choose to come into being and to live, he is said to have answered the question by saying: "To observe [theasasthai] the heavens and the stars, moon and sun in them," everything else being nothing worth. ${ }^{30}$

In the Natorp-Bericht, Heidegger briefly points out how decisive this Aristotelian interpretation of the essence and actuality of human life has been for the entire later tradition of thought, for what Heidegger calls the "Graeco-Christian interpretation of life." 31 In 
Aristotle's treatises Heidegger sees at work the constant tendency of Western thought to what he was later to call "forgetfulness of being" (Seinsvergessenheit), especially in its fundamental "ethical" aspect as forgetfulness of human being. Aristotle's conclusion - bios theōrêtikos as the most perfect form of life - is, in a sense, inevitable, granted that ousia is from the outset accepted as the most fundamental sense of being.

In Book VI of the Nicomachean Ethics - a text to which Heidegger devoted the first part of his famous lecture course on Plato's Sophist in 1924-25 - Aristotle defines the five "virtues of discursive thought" (arētai dianoètikai) through which the soul "dwells in the disclosedness of beings" (alētheuei): know-how (technē), intellectual mastery (epistēmēe), situational prudence (phronēsis), comprehensive understanding (sofia), immediate insight (nous). ${ }^{32}$ Of these, the two principal faculties are phronessis, i.e., the ability to disclose the active situations of life through the inherent possibilities that they offer for the appropriate life as a whole, and sophia, i.e., comprehension of reality in its fullness with a view to its fundamental and immutable principles and structures. ${ }^{33}$ At the end of Book VI, Aristotle addresses the question: which of these is the superior and more profound way of access to the disclosedness of beings? Here Aristotle makes an ontological choice which, in the horizon of ousia, seems inevitable.

Thus it is evident that sophia must be the most rigorous form of knowledge [epistēmē]. [. . .] For it would be quite out-of-place [atopon] if someone should judge [. . .] phronēsis to be the most profound kind of knowledge, unless humans were to be superior to all the other beings in the celestial order $[$ kosmos $]{ }^{34}$

The fundamental reason for this is that phronesis, which discloses lived reality by grasping each situation in its possibilities, is directed at that which is "contingent," admits of being 
otherwise (ta endechomena allōs echein), and in fact always is otherwise ${ }^{35}$ - no two lived situations are the same, each one is unique - whereas sophia articulates meaningfulness through the fundamental and necessary principles that are never other than what they are. ${ }^{36}$ In other words, phronēsis refers to the non-permanence, goal-orientedness, historicity, temporality and contingency of concretely lived human situations, while sophia is related to what is most permanently present, thus most being, most real.

The ultimate ethical criteria for the determination of the perfection and full actuality of human life are thus not taken from the structures of human living itself, but from what is permanently and unchangingly present, "divine." Still, phronēsis, mindfulness of the situation, is the primary form of access to reality, in that it is impossible to carry out the proper goals and ends of human life if one is not first able to grasp and to act out the singular lived situations in view of these goals and ends. "From what has been discussed, it is quite clear that one is not fit to be excellent [agathon] in the proper sense without phronēsis. ${ }^{, 37}$ In his reading of Aristotle's treatment of phronēsis, Heidegger finds that Aristotle discovers here the temporal structure of what in Being and Time is called the Augenblick, the "glance of the eye" 38 - the indivisible moment, the unique situation of action and living, the kairos. ${ }^{39}$ Phronēsis grasps each situation in its singularity and makes it possible to "act out" this situation, thus allowing praxis. It is defined by Aristotle as a "discursive [meta logou] and disclosing [alēthē faculty in the context of acting out [praktikē], concerned with what is expedient for humans." ${ }^{\prime 4}$ Phronesis is simply the human ability to discover the proper purposes and goals of one's temporal life as well as the temporality of life as such - it comprehends the types of intentionality which in Being and Time are referred to as prudence or circumspection (Umsicht), conscience (Gewissen) and resoluteness (Entschlossenheit). ${ }^{41}$

As many Heidegger scholars have shown, it is obvious that the published part of Being and Time largely builds on Book VI of the Nicomachean Ethics, especially on the 
treatment of phronēsis, which Heidegger develops, articulates and radicalizes. ${ }^{42}$ What Heidegger wants to do here is to give Aristotle "a new chance"43 - to work out those elements and to enact those possibilities of Aristotle's phenomenology that were disregarded by the later tradition which, while building on the Aristotelian treatises, appropriated mainly those elements in Aristotle that serve the general metaphysics of ousia. These elements were then stiffened into dogmatic theses that gradually covered over the concrete phenomenological problems that Aristotle is struggling with. ${ }^{44}$ Notably, the main phenomenon that Heidegger seeks to un-cover, the phenomenon that is "beyond" ousia and in fact the prerequisite for all meaningful presence, is the transcendent mobility of living.

\section{Unfinished presence}

Kinēsis, movement, elaborated in the Physics and in Book Theta of the Metaphysics, is one of Aristotle's fundamental concepts. Its meaning is not limited to spatial locomotion; in its broadest sense, kinēsis - sometimes synonymous with metabolè, transition - denotes all kinds of processes that there are, all change and alteration, all becoming in general. The very first chapter of the Physics declares movement to be a basic reality which simply has to be dealt with: "Let it be laid down as a foundation for us [in our investigation] that either all or some of the beings that come to be [ta physei] are in motion. This is evident on the basis of induction [epagōgē, i.e., letting the phenomena guide us to their general structure]."45

What makes this point of departure radical is the fact that change and movement were by many earlier thinkers regarded as the very opposites to being in the Greek sense of beingpresent and being-complete, and therefore excluded from philosophical consideration. In his poem, Parmenides makes it clear that since there is being and since there is no non-being, there can be no change or becoming, since that would entail something coming into being, into presence, from non-being, non-presence, and vice versa - what $i s$, then, is one and 
unified, "untrembling," all at once. ${ }^{46}$ It is a commonplace that the Eleatics, the school of Parmenides, denied the reality of movement altogether; Zeno of Elea devised his famous paradoxes to show the impossibility of even thinking movement and change consistently. ${ }^{47}$ According to Aristotle, the reason why these philosophers could not come to terms with the reality of movement was their inability to distinguish between absolute (haplōs) and contingent or relative (kata symbebēkos) non-being, between (a) simply not being and (b) not being for now but being capable of coming into being. ${ }^{48}$ The necessity of reformulating the thesis of Parmenides had already been seen by Plato in the Sophist: "In order to defend ourselves, it will be necessary for us to put to test the discourse of father Parmenides and to drive through by force [the thesis] that non-being [to $m \bar{e} o n]$, in a certain respect, is, and as to being [to on], in turn, that it in a certain sense is not." 49

In his last full-length lecture course on Aristotle from 1931 - a kind of culmination in the encounter with Aristotle - Heidegger discusses at length Aristotle's dispute with the Megarian school in Metaphysics Theta, Ch. $3{ }^{50}$ Aristotle tells us here that according to the Megarians - contemporaries of Aristotle and intellectual descendants of Parmenides - it is not true to say that a builder is capable (dynasthai) of building a house if he or she is not actually at work (energein) building it. ${ }^{51}$ This seems to be very obviously false, but in fact, Heidegger points out, Aristotle has to take this argument very seriously, as it is quite consistent with the basic Greek conception of what "is" means. ${ }^{52}$ What the Megarians mean to say is that the builder's capacity to build is not present, does not show itself, when it is not being exercised, that is, when the builder is not building. There cannot be any such thing as a pure, unrealized and merely potential possibility or capacity, dynamis - pure possibilities are not present, precisely because they are unrealized. Only what is fully carried out, energeia, is real and present. But in denying the reality of dynamis the Megarians, just like the Eleatics, are ultimately led to deny the reality of all movement, becoming and change, of all kinessis in 
general. ${ }^{53}$ For without the capacity to build the builder can never start building, in fact, the builder cannot be a builder, since it is on the basis of the capacity to build that he or she appears to us as a builder. ${ }^{54}$ In the same manner, if we follow the reasoning of the Megarians, there is no sense in saying that a house is now being built, in the process of being built, but is not yet finished - for there is no house present before there is a finished house. If, then, that which is not completely present and finished is simply non-present, simply non-real and nonexistent, it can never be coming to presence. Thus nothing can ever come to be or cease to be.

For, [if we follow the argument of the Megarians,] the one who is already standing will always remain standing and the one who is already seated will remain seated, as this person will not stand up again once seated; for precisely the one who is not capable [dynaton] of standing up will be incapable of standing up. Now, if such things do not admit of being meaningfully articulated [legein], it is evident that capacity-to-be [dynamis] and being-already-operative [energeia] are different $[\ldots]$, so that a thing capable of being something admits of [endechetai] not being [what it is capable of being], and accordingly, a thing capable of not being [something] admits of being [what it is capable of not being] [...]. ${ }^{55}$

We all see that things change, come to be something and cease to be something else. Moreover, as in the case of the builder, phenomena that change are meaningfully present to us in view of their yet unrealized capacities and possibilities, that which they are capable of being. The idle builder is, in a way, present to us as a builder, and a construction site is somehow present to us as a building that is still being built. Aristotle gives many other examples: what is cold or warm to touch or tastes sweet is considered to be cold, warm or 
sweet even when it is not presently felt or tasted, and the person who normally sees is not thought to be blind whenever his or her eyes happen to be closed. ${ }^{56}$ The meaningful presence of the builder, of the unfinished house, of the warm fire and of the blind person is constituted by the respective dynamis of each of these beings - that is, by the present reference to what they are presently not but what they are capable of becoming, what is only relatively absent ${ }^{57}$ from them. It is this structure of dynamis as a constitutive relation to relative absence which must be kept in mind when interpreting Aristotle's definition: "To be capable [dynaton] is [esti] to be something that, at the point where the being-operative [energeia] of that to which it is said to have the capacity starts to be present in it, will not be [estai] incapable in any respect." 58

Heidegger calls this seemingly circular and trivial "definition" - what is not incapable is capable - an expression of "the greatest philosophical knowledge of antiquity," "a knowledge which even today remains unappreciated and misunderstood in philosophy." $59 \mathrm{He}$ does not really tell us why this is so. However, paying attention to the tenses used in Aristotle's statement may dispel its circularity and help to understand the importance Heidegger attaches to it. What is present (esti) as capable of something is present as such that it will not (estai) be incapable of carrying out the full presence of its capacity. The unemployed builder is now present to us as a builder precisely because we understand the builder to be so disposed that, once the activity building of starts, he or she will be able to carry out this activity in its full extent and in all of its aspects. A slab of marble shows itself to us as a can-be marble sculpture precisely insofar as it is understood to be such that once the activity of carving a sculpture begins, there is nothing essential in the marble itself to stop it from going through the entire process leading to the purpose and end of carving, to the finished sculpture. 
Aristotle does not give us an abstract definition of what being-capable is; he gives rather a phenomenological indication of how something capable is present as capable of something. ${ }^{6}$ From a Heideggerian viewpoint, the unique importance - and also the fundamental difficulty - of this indication must lie in the fact that being-present is here described in terms of the future, of what is not yet present. In his definition of dynamis, Aristotle thus comes across the temporal character of being, the transcendent constitution of meaningful presence through the non-present, the essential relation to absence that constitutes presence. This is precisely the "kinetic meaning of being-ness" which, according to Thomas Sheehan, is what Heidegger's philosophy is all about. ${ }^{61}$

According to this reading, kinēsis and dynamis are the two Aristotelian concepts that offer the most radical possibilities for reappropriation. They are intimately interconnected and, in fact, mutually define one another. According to the famous definition in Book III of the Physics, movement is nothing but precisely the full and complete presence of that which is not yet present fully but only in capacity (dynamei on), precisely insofar as it is something that can and may be and thus is not yet. ${ }^{62}$ Thus the actual kinessis of house building is simply the meaningful presence of a house that is not yet fully present but presently coming to presence. For Heidegger, this definition of movement is part and parcel of Aristotle's great achievement in comparison with the earlier and the later tradition. It is precisely the ontological grasp of kinēsis that makes, for Heidegger, the Physics - instead of the Metaphysics - "the hidden, and therefore never adequately studied, foundational book of Western philosophy." 63

Aristotle's other main characterization of kinēsis is equally decisive:

The reason why movement appears to be something indefinite [aoriston] is that it is not <simply> to be placed under the capacity nor under the being-operative of what-is [. . .] 
Movement seems to be a kind of being-operative, but an unfinished [atelēs] one: the reason for this is that the capable being [to dynaton], of which movement is the beingoperative, is unfinished. ${ }^{64}$

Being-in-motion is a form of being present, actualized, energeia, but it is an unfinished (atelēs) presence, a presence from which something is still lacking and which cannot be understood without reference to an end that is not yet present.

In short, in phenomenologically elaborating the structures of dynamis and energeia, Aristotle gains an initial understanding of the phenomenon of world (Welt) in Heidegger's sense - of the significance (Bedeutsamkeit) of the world that is given in the mode of "handiness" (Zuhandenheit) ${ }^{65}$, in which particular worldly beings gain their sense through their historical and cultural context of reference (Bewandtnis) and through their futural "forwhat-purpose," their "in-order-to" (um zu) character. The most general structure of this significant givenness of beings is the temporality of being (Temporalität des Seins) that Heidegger intended to work out in the missing Division 3 of Part I of Being and Time, "Time and Being," and later reworked under the title Ereignis. ${ }^{66}$ The temporality of being - that is, the temporal constitution of all meaningfulness - correlates with the ecstatic temporality of Dasein itself ${ }^{67}$ : the self-transcendence of the opening $(D a)$ as the context for all possible sense is a precondition for the self-transcendent givenness of beings within this context. The motivated movedness of living is not just one kind of movement or process - it is precisely the movement that renders possible the motional, kinetic givenness of all reality. In 1926, Heidegger argues that "it is indeed precisely the initial phenomenological grasp on life that led to the interpretation of movement and allows the radicalization of ontology." 68 The horizon for Aristotle's revolutionary analysis of movement is a pre-ontological understanding of the motional and motivated essence of life itself. 


\section{Divine and mortal motivation}

Aristotle, like the long philosophical tradition after him, is fully aware of the constitutive role of the living consciousness for all meaningful presence: in his treatise on the soul he says that "the soul [psychē; understood simply as the principle of life, animation] is, in a way, all of what-is." ${ }^{69}$ But despite many intimations, neither Aristotle nor the long metaphysical tradition after him thematized the way of being of this context for all possible meaningfulness and beingness - the soul, the spirit, consciousness - as an ecstatic, externally motivated movement, as existence.

Yet, as we saw, Heidegger claims that "the ontological structure of human being" in Aristotle "becomes comprehensible on the basis of the ontology of beings in the mode of a specific movedness." In other words, Aristotle does indeed find the full actuality of human being in a specific kind of movement. The character of this movement is explicated by Heidegger very clearly:

Being is [for Aristotle] being-finished-and-ready [Fertigsein], i.e., a kind of being in which movement has arrived at its end. The being of life is seen as a movedness running its course within itself, and indeed human life is in this movedness when it has arrived at its end with regard to its ownmost possibility of movement, that is, pure and simple apprehending. [...] First, as pure and simple apprehending, nous is in its genuine movedness when it has given up all concern for carrying out [ausrichtendes Besorgen] and only apprehends. Second, as this apprehending, it is a movedness that, in having arrived at its end insofar as that which is purely apprehensible now stands before its gaze, not only does not cease, but rather now - precisely as having arrived at 
its end - really is movement for the first time. [. . .] It is only noēsis as pure theōrein that satisfies the highest idea of pure movedness. ${ }^{70}$

As we have seen, the full actuality and essence of life is not, in Aristotle's eyes, to be found in an ecstatic outward movement. Life is fully actualized only when it has come to rest and reached the fullest possible self-immanence in theōrein, in contemplation and beholding. But theōrein is still a verb: an enactment of living, a praxis. As Heidegger repeatedly points out, being-at-rest is a mode of mobility - being-at-rest does not make any sense without an inherent possibility of movement.

The purest manifestation of the essence of movedness is to be found where rest does not mean the breaking off and cessation of movement, but rather where movedness is gathered up into standing still, and where this ingathering, far from excluding movedness, includes and for the first time discloses it. ${ }^{71}$

In theōrein, life indeed ceases its ecstatic and self-transcendent movement toward itself as a possibility, as a not-yet, and concentrates upon what is fully present. But in thus coming to rest, living is not deprived of movement. Instead, its mode of motivation changes. The movement of life is no longer motivated by something external, by possibilities, by the "notyet," it is no longer directed outwards; it is now motivated by the simple and immediate intuitive reception (nous, noein) of what is completely present as such. ${ }^{72}$ In theorrein, the human being no longer reaches beyond its own limits, it is no longer pitched towards exteriority and otherness; it simply "actively" remains itself, living within the boundaries of its own essence, as a self-present and self-identical receptacle of the presence of the present. 
The externally motivated, ecstatic and transcending movement of life becomes the internally motivated and self-immanent movement of resting within oneself.

In Metaphysics Theta, Ch. 6, Aristotle reserves the name kinēsis only for the first type of movement, which is always unfinished (ateless), and prefers to call the latter type an energeia, "being-already-operative."73 Even though he up to now has mainly used the word energeia to describe the completeness of produced objects, here all his examples of energeia are lived activities (praxeis): seeing, considering, apprehending, proper living and being happy.

None of the activities [praxeis] for which there is a limit [peras] is an end [telos] [in itself], but these are rather activities that are concerned with the end [...], and as that for the sake of which [hōn heneka] the movement takes place is not present [in the movement itself], they are not praxis, or at least they are not complete praxis, for they are not ends [in themselves]. But the other kind [of activity - i.e., besides the unfinished activity, which is not true praxis - is truly praxis], insofar as the end and the activity itself are both present. For example, one has, while seeing, <at once already attained sight,> one has, while still considering, <already attained consideration,> one has, while still apprehending, already attained apprehension; whereas, while still learning [something], one has not already learned [it], and while still getting well, one has not already got well. While living properly, one has at once [hama] already attained a proper life, and while being happy, one has already attained happiness. ${ }^{74}$

For Heidegger, energeia and entelecheia in their fundamental sense mean, for each being, the movement of remaining within, inhabiting its ownmost eidos, its form, that is also its telos what this being as such most properly is. For humans, the most perfect energeia would thus 
be the most perfect praxis, the most perfect way of actively living one's life while having already reached perfection. As has already been shown, this supreme praxis is the pure beholding and contemplation of permanent truths. For humans, theōrein is an intimation of the activity of the divinity, noēsis noēseōs, of apprehension apprehending its own activity. The divinity is the immobile, unmoved mover; but since the divinity is said to be a life which is constantly like the one we live at our very best, its immobility cannot be understood negatively as a lack of activity. ${ }^{75}$ Instead, the divinity has a motivation of its own: it is the self-immanent activity of a perfectly self-transparent and self-coincident self-awareness. "The theion is noēsis noēseōs only because of the fact that with regard to the basic character of its being, i.e., to its movedness, such apprehending satisfies most purely the idea of beingmoved as such."76

The Heideggerian reappropriation of Aristotle is thus not a simple transformation of a "static" understanding of life into a "dynamic" and "kinetic" conception of living. It is rather the transition from one understanding of the movedness of life into a more original form of movement - the transition from a divine to a mortal mobility, the translation of the "theological" Western ontology into a more archaic, "anthropological" one. The Greeks thought movement and activity on the basis of the paradigmatic activity of resting in perfection; Heidegger seeks to think the most fundamental movement, the movement of human living, as one that never comes to a halt and never attains perfection, if not precisely in its imperfection. The effort of Being and Time is to show how a finite, imperfect, ecstatic, self-transcendent and outward-motivated movedness is the necessary but overlooked ontological horizon and background for the constitution of the ideal of an infinite, perfect, self-immanent and inward-motivated movement of living. 
I would like to thank Rudolf Bernet, Søren Overgaard, Thomas Schwarz Wentzer, Dan

Zahavi and an anonymous referee for their helpful comments on this paper and on an earlier

version.

\section{NOTES}

${ }^{1}$ On this transformation, see Theodore Kisiel, The Genesis of Heidegger's Being and Time (Berkeley: University of California Press, 1993), 311-314.

${ }^{2}$ This is a central thesis in most of Sheehan's writings on Heidegger. In particular, see Thomas Sheehan, "Heidegger: From Beingness to the Time-Being," Listening 7 (1973): 22; "Getting to the Topic: The New Edition of Wegmarken," in Radical Phenomenology: Essays in Honor of Martin Heidegger, ed. John Sallis (Atlantic Highlands: Humanities Press, 1978), 313; "Heidegger's Interpretation of Aristotle: Dynamis and Ereignis," Philosophy Research Archives 4/4 (1978): 279; "Heidegger's Topic: Excess, Recess, Access," Tijdschrift voor Filosofie 41/4 (1979): 634-635; "Introduction: Heidegger, the Project and the Fulfillment," in Heidegger: The Man and the Thinker, ed. Thomas Sheehan (Chicago: Precedent Publishing, 1981), xviii-xix; "On Movement and the Destruction of Ontology," The Monist 64/4 (1981): 536-537; "On the Way to Ereignis: Heidegger's Interpretation of Physis," in Continental Philosophy in America, ed. Hugh J. Silverman, John Sallis, Thomas M. Seebohm (Pittsburgh: Duquesne University Press, 1983), 132-133; "Heidegger's philosophy of mind," in Contemporary Philosophy: A New Survey, Vol. 4: Philosophy of Mind, ed. Guttorm Fløistad (The Hague: Nijhoff, 1983), 307-308; “'Time and Being,' 1925-7," in Martin Heidegger: Critical Assessments, Vol. I: Philosophy, ed. Christopher Macann (London: Routledge, 1992), 62.

The fundamental importance of the Aristotelian dynamis and kinessis for Heidegger, especially for his early phenomenology of life, is also emphasized by Rémi Brague, "La phénoménologie comme voie d'accès au monde grec: Note sur la critique de la Vorhandenheit comme modèle ontologique dans la lecture heidéggerienne d'Aristote," in Phénoménologie et métaphysique, ed. Jean-Luc Marion, Guy Bonjour-Planty (Paris: Presses Universitaires de France, 1984), 247-273; Walter Brogan, "Heidegger's Interpretation of Aristotle on the Privative Character of Force and the Twofoldness of Being," in Interrogating the Tradition: Hermeneutics and the History of Philosophy, ed. Charles E. Scott, John Sallis (Albany: State University of New York Press, 2000), 111-130; John D. Caputo, "Heidegger's Kampf: The Difficulty of Life," Graduate Faculty Philosophy Journal 14/2-15/1 (1991): 61-83; Brian Elliott, Anfang und Ende in der Philosophie: Eine Untersuchung zu Heideggers Aneignung der aristotelischen Philosophie und der Dynamik des hermeneutischen Denkens (Berlin: Duncker \& Humblot, 2002), 128-154; Helen Fielding, "Questioning nature: Irigaray, Heidegger and the potentiality of matter," Continental Philosophy Review 36/1 (2003): 1-26; Hans-Georg Gadamer, "Heidegger und die Griechen," in Gesammelte Werke, 10: Hermeneutik im Rückblick (Tübingen: Mohr, 1995), 43-45; Catriona Hanley, "Heidegger on Aristotle's Metaphysical God," Continental Philosophy Review 32/1 (1999): 19-28; Being and God in Aristotle and Heidegger: The Role of Method in Thinking the Infinite (Lanham: Rowman \& Littlefield, 2000), 163; "Force and Dynamism in Aristotle and Heidegger: Becoming What You Are... To Be," in Life: Energies, Forces and the Shaping of Life: Vital, Existential, ed. Anna-Teresa Tymieniecka (Dordrecht: Kluwer, 2002), 3-18; Ted Sadler, Heidegger and Aristotle: The Question of Being (London: Athlone, 1996), 58-57; Franco Volpi, "La 'riabilitazione' della dynamis e dell'energeia in Heidegger," Aquinas 33 (1990): 3-27; Charlotta Weigelt, The Logic of Life: Heidegger's Retrieval of Aristotle's Concept of Logos (Stockholm: Almqvist \& Wiksell, 2002), 134-139, 190-223.

${ }^{3}$ The "Natorp account" (Natorp-Bericht), titled "Phenomenological Interpretation in Connection with Aristotle: An Indication of the Hermeneutical Situation," is a brief outline for the original Aristotle project, written in October 1922 as a response to queries from Prof. Paul Natorp (Marburg) and Prof. Georg Misch (Göttingen) concerning Heidegger's intended publications. It apparently helped to secure Heidegger's appointment to the associate professorship in Marburg in 1923. The manuscript remained unpublished until 1989. See Kisiel, The Genesis of Heidegger's Being and Time, 248-252.

${ }^{4}$ The expression Lebensbewegtheit or Bewegtheit des Daseins also plays a central part in the lecture course from the winter semester 1921-1922 (Phänomenologische Interpretationen zu Aristoteles: Einführung in die phänomenologische Forschung, Gesamtausgabe, 61 (Frankfurt am Main: Klostermann, 1985), 116-155 
[hereafter, GA 61] / Phenomenological Interpretations of Aristotle: Initiation into Phenomenological Research, tr. Richard Rojcewicz (Bloomington: Indiana University Press, 2001), 87-115) and it is found in the lectures from summer 1923 (Ontologie (Hermeneutik der Faktizität), Gesamtausgabe, 63 (Frankfurt am Main: Klostermann, 1982), 65 [hereafter, GA 63] / Ontology - The Hermeneutics of Facticity, tr. John van Buren (Bloomington: Indiana University Press, 1999), 51) and summer 1926 (Die Grundbegriffe der antiken Philosophie, Gesamtausgabe, 22 (Frankfurt am Main: Klostermann, 1993), 186 [hereafter, GA 22]).

It should of course be noted that in Being and Time, Heidegger explicitly distinguishes Dasein, as ontologically more fundamental, from "life" (Leben) as studied by biology; Sein und Zeit, $18^{\text {th }}$ ed. (Tübingen: Niemeyer, 2001), § 10 [hereafter, SZ] / Being and Time, tr. John Macquarrie, Edward Robinson (Oxford: Blackwell, 1962), Section 10. However, in his first courses Heidegger preferred the expression "factical life" (faktisches Leben), which is still used as interchangeable with Dasein in 1923 (GA 63, 7 / Ontology - The Hermeneutics of Facticity, 5). All in all, the decision to avoid the expression "life" seems to be based on its misleading associations with biology, "philosophy of life" and, later, with Nietzsche. Cf. Kisiel, The Genesis of Heidegger's Being and Time, 141, 147, 493.

5 Heidegger, "Phänomenologische Interpretationen zu Aristoteles (Anzeige der hermeneutischen Situation)" [1922], Dilthey-Jahrbuch für Philosophie und Geschichte der Geisteswissenschaften 5 (1989): 261 [hereafter, PIA] / "Phenomenological Interpretations in Connection with Aristotle: An Indication of the Hermeneutical Situation," tr. John van Buren, in Supplements: From the Earliest Essays to Being and Time and Beyond, ed. John van Buren (Albany: State University of New York Press, 2002), 137. Translation modified.

6 Besides the PIA, Heidegger discusses the Aristotelian kinēsis especially in Die Grundbegriffe der aristotelischen Philosophie [1924], Gesamtausgabe, 18 (Frankfurt am Main: Klostermann, 2002), 283-329, 378-395 [hereafter, GA 18]; GA 22, 170-181; Die Grundprobleme der Phänomenologie [1927], Gesamtausgabe, 24 (Frankfurt am Main: Klostermann, 1975), 324-388 [hereafter, GA 24] / The Basic Problems of Phenomenology, tr. Albert Hofstadter (Bloomington: Indiana University Press, 1982), 229-274; "Vom Wesen und Begriff der Physis: Aristoteles, Physik B, 1", in Wegmarken, $3^{\text {rd }}$ ed. (Frankfurt am Main: Klostermann, 1996), 239-301 [hereafter, WM] / "On the Essence and Concept of Physis in Aristotle's Physics B, 1," tr. Thomas Sheehan, in Pathmarks, ed. William McNeill (Cambridge: Cambridge University Press, 1998), 183-230. According to Theodore Kisiel's résumés, the problem of kinēsis played a central part in the 1920 seminar on De anima, in the lecture course of summer semester 1922 (forthcoming as vol. 62 of the Gesamtausgabe) and the 1922-23 seminar on Nicomachean Ethics VI, Metaphysics Z and De anima (Kisiel, The Genesis of Heidegger's Being and Time, 230-232, 238-248, 271-274). The entire course of 1931 is devoted to the concept of dynamis: Aristoteles, Metaphysik $\Theta$ 1-3: Von Wesen und Wirklichkeit der Kraft, Gesamtausgabe, 33 (Frankfurt am Main: Klostermann, 1981) [hereafter, GA 33] / Aristotle's Metaphysics $\Theta$ 13: On the Essence and Actuality of Force, tr. Walter Brogan, Peter Warnek (Bloomington: Indiana University Press, 1995).

${ }^{7}$ On the interpretation of ousia, see GA 18, 21-35; Platon: Sophistes [1924-25], Gesamtausgabe, 19 (Frankfurt am Main: Klostermann, 1992), 269-270, 466-467 [hereafter, GA 19] / Plato's Sophist, tr. Richard Rojcewicz, André Schuwer (Bloomington: Indiana University Press, 1997), 186-187, 323; SZ, 25 / Being and Time, 47; GA 24, 152-153 / Basic Problems of Phenomenology, 108-109; Vom Wesen der menschlichen Freiheit: Einleitung in die Philosophie [1930], Gesamtausgabe, 31 (Frankfurt am Main: Vittorio Klostermann, 1994), 40-73 / The Essence of Human Freedom: An Introduction to Philosophy, tr. Ted Sadler (London: Continuum, 2002), 29-51.

${ }^{8}$ These initial criteria of ousia are laid out in Categories (Categoriae et Liber de interpretatione, ed. L. MinioPaluello (Oxford: Oxford University Press, 1949)), 5.2a11-4b19 and in Metaphysics (Aristotle's Metaphysics, Vol. I-II, ed. W. D. Ross (Oxford: Oxford University Press, 1924)), $\Delta .8$ [hereafter, Met.]. At the outset of Met. $\mathrm{Z}(1.1028 \mathrm{~b} 2-4)$ Aristotle transforms the question "what is that-which-is?" [ti to on?] into the question "what is ousia?" What he is basically asking is what kind of being best fulfills the initial and pre-given sense of being as ousia, and this question is then pursued throughout the books $\mathrm{Z}, \mathrm{H}$ and $\Theta$.

${ }^{9}$ For an overview of this history of metaphysics as a "history of being," see e.g. Nietzsche, Zweiter Band, $6^{\text {th }}$ ed. (Stuttgart: Neske, 1998), 363-438 [hereafter, N II] / "Metaphysics as History of Being" and "Sketches for a History of Being as Metaphysics," in The End of Philosophy, tr. Joan Stambaugh (Chicago: University of Chicago Press, 2003), 1-74, as well as "Überwindung der Metaphysik," in Vorträge und Aufsätze, 9 $9^{\text {th }}$ ed. (Stuttgart: Neske, 2000), 67-95 / "Overcoming Metaphysics," in The End of Philosophy, 84-110.

${ }^{10}$ See, in particular, SZ, 12-13, 133, 328-329 / Being and Time, 32-33, 171, 377 and also Heidegger's marginal note c to page 133 at SZ, 442 .

${ }^{11}$ Sich-vorweg-schon-sein-in(der-Welt-) als Sein-bei (innerweltlich begegnendem Seienden). SZ, 192 / Being and Time, 236.

${ }^{12}$ PIA, 240 / "Phenomenological Interpretations in Connection with Aristotle," 115. 
${ }^{13}$ This is the true meaning of the Heideggerian dictum, made famous and largely misunderstood by Sartre, that the "essence [Wesen] of Dasein lies in its existence" (SZ, 42 / Being and Time, 67; cf. 318/365 and "Brief über den 'Humanismus'," in WM, 325-329 / "Letter on 'Humanism'," tr. Frank A. Capuzzi, in Pathmarks, 248251). "Selfhood [Selbstheit] is to be discerned existentially only in one's proper capacity-to-be-oneself [Selbstseinkönnen] - that is to say, in the properness of Dasein's being as care [Sorge]. In terms of care the constancy of the self, as the supposed persistence of the subjectum, gets clarified. [...] Existentially, selfconstancy [Selbstständigkeit] signifies nothing other than anticipatory resoluteness [Entschlossenheit]. [...] care does not need to be founded in a self. But existentiality, as constitutive for care, provides the ontological constitution of Dasein's self-constancy [...]." (SZ, 322-323 / Being and Time, 369-370. Translation modified.)

${ }^{14}$ SZ, 364 / Being and Time, 416. Translation modified.

${ }^{15}$ See GA 18, 295-297, 367-370; GA 22, 172-175; WM, 282-287 / "On the Essence and Concept of Physis," 215-219; N II, 363-373 / "Metaphysics as History of Being," 1-10.

${ }^{16}$ GA 61, 93 / Phenomenological Interpretations of Aristotle, 70.

${ }^{17}$ Energeia is translated as "being-already-operative" by Sheehan; e. g. "How (Not) to Read Heidegger," American Catholic Philosophical Quarterly 69/2 (1995): 282.

${ }^{18}$ In the 1923 lectures, Heidegger exclaims: "Dasein [...] is, though as the being-on-the-way [Unterwegs] of itself to itself!" (GA 63, 17 / Ontology - The Hermeneutics of Facticity, 13.)

${ }^{19}$ The distinction between poiessis and praxis, producing and acting out, is made at Nicomachean Ethics, (Ethica Nicomachea, ed. L. Bywater (Oxford: Oxford University Press, 1894)), VI.5.1140b3-4, 6-7 [hereafter, NE]: "[. . .] producing [poiessis] and acting out [praxis] are different in kind. [...] For the end [telos] of producing is other [than the process of production itself], whereas the end of acting out could not be [other than the acting out itself]. For proper action is itself an end." (My translation.)

${ }^{20}$ SZ, 236 / Being and Time, 279-280.

${ }^{21}$ On this point my interpretation differs somewhat from that of Jacques Taminiaux in "La réappropriation de l'Ethique à Nicomaque: poiēsis et praxis dans l'articulation de l'ontologie fondamentale," in Lectures de l'ontologie fondamentale: Essais sur Heidegger (Grenoble: Millon, 1989), 147-189 / "The Reappropriation of the Nicomachean Ethics: Poiesis and Praxis in the Articulation of Fundamental Ontology," in Heidegger and the Project of Fundamental Ontology, tr. Michael Gendre (Albany: State University of New York Press, 1991), 111-137. I fully agree with Taminiaux when he says that in the period of fundamental ontology, Heidegger is "radicalizing" the Aristotelian concept of praxis (166/124). However, Taminiaux also sees Heidegger's phrase "Dasein exists for the sake of itself" as a simple "transposition of the Aristotelian theory of praxis" (165/124), implying that the structure of the transcendent temporality of Dasein is the structure of praxis as such. This interpretation is reiterated in La fille de Thrace et le penseur professionnel: Arendt et Heidegger (Paris: Payot, 1992), 56-64 / The Thracian Maid and the Professional Thinker: Arendt and Heidegger, tr. Michael Gendre (Albany: State University of New York Press, 1997), 38-45, even though Heidegger is here said to "metamorphose" the Aristotelian praxis into the finite existence of Dasein, thereby disregarding, in a "solipsistic" manner, the elements of plurality and political life involved in praxis.

${ }^{22}$ See NE X.7.1177a12-18. Cf. GA 19, 174-179 / Plato's Sophist, 119-123.

${ }^{23} N E$ X.7.1177a19-b1.

${ }^{24}$ See Heidegger, Einleitung in die Philosophie [1928-29], Gesamtausgabe, 27 (Frankfurt am Main: Klostermann, 1996), 174-179. In the Politics Aristotle makes the point that what is truly "practical" is not, as is commonly thought, that which is directed at the separate results of the practices of life, but instead precisely the kind of beholding and considering things that does not take place for the sake of any external end or result. "The man of praxis does not have to be in relation to others, as some would have it, nor is it necessary that only the considerations that take place in view of the results of the praxis are related to praxis. It is much rather necessary that those forms of theoria and those considerations that are complete in themselves and take place for the sake of themselves [are related to praxis]: for proper praxis, and thus a certain praxis, is an end." (Politica, ed. W. D. Ross (Oxford: Oxford University Press, 1957),VII.3.1325b16-21. My translation.)

${ }^{25}$ NE X.7.1177b31-34; cf. GA 19, 178 / Plato's Sophist, 122.

${ }^{26} N E$ X.7.1177b26-31.

${ }^{27}$ PIA, 263 / "Phenomenological Interpretations in Connection with Aristotle," 139; GA 19, 242 / Plato's Sophist, 166-167; GA 22, 179; Metaphysische Anfangsgründe der Logik im Ausgang von Leibniz [1928], Gesamtausgabe, 26 (Frankfurt am Main: Klostermann, 1978), 13 [hereafter, GA 26] / The Metaphysical Foundations of Logic, tr. Michael Heim (Bloomington: Indiana University Press, 1984), 11.

${ }^{28}$ Met. $\Lambda .9 .1074 \mathrm{~b} 15-35$.

${ }^{29}$ Met. $\Lambda .7 .1072 b 28-30$. My translation.

${ }^{30}$ Ingemar Düring, Aristotle's Protrepticus: An Attempt at Reconstruction (Gothenburg: Acta Universitatis Gothoburgensis, 1961), B 19. Aristotle is known to have addressed his Protrepticus, an exhortation to philosophy written in popular style, to Themison, a prince of Cyprus. Düring's reconstruction of this work is 
based on anonymous quotes drawn from the Protrepticus of the Neoplatonist Iamblichus of Chalcis $\left(3^{\text {rd }}\right.$ century A.D.). See Düring, Aristotle's Protrepticus, 11-39.

${ }^{31}$ PIA, 250-251 / "Phenomenological Interpretations in Connection with Aristotle," 124-126; cf. SZ, 48-49 /

Being and Time, 73-75.

${ }^{32} N E$ VI.3.1139b15-17.

${ }^{33}$ For Aristotle's analysis of phronēsis, see NE VI.5.1140a24-b30; of sophia, see NE VI.7.1141a9-20.

${ }^{34} N E$ VI.7.1141a16-17, 20-22. My translation.

${ }^{35} N E$ VI.5.1140a31-b4, b27-28; 7.1141b9-23.

${ }^{36} N E$ VI.6.1141a1-3; 7.1141b2-3; cf. GA 19, 135-138, 168-171 / Plato's Sophist, 93-95, 116-118.

${ }^{37} N E$ VI.13.1144b30-31. My translation.

${ }^{38}$ According to Taminiaux ("The Interpretation of Aristotle's Notion of Aretê in Heidegger's First Courses," tr. Jennifer Hansen, in Heidegger and Practical Philosophy, ed. François Raffoul, David Pettigrew (Albany: State University of New York Press, 2002), 26), in the Sophist lectures Heidegger "subscribed to the [Aristotelian, or rather Platonic,] priority of bios theoretikos". In William McNeill's (The Glance of the Eye: Heidegger, Aristotle, and the Ends of Theory (Albany: State University of New York Press, 1999), 17-54) reading, however, the kind of "seeing" that Heidegger seeks to "rehabilitate" here is precisely the instantaneous and temporal "glance of the eye" that Aristotle calls the nous of phronessis, rather than the self-immanent, complete and supratemporal vision of theōria.

39 See GA 19, 163-164 / Plato's Sophist, 112-113; GA 22, 312-313; GA 24, 409 / Basic Problems of Phenomenology, 288.

${ }^{40} N E$ VI.5.1140b20-21. My translation.

${ }^{41}$ In the Sophist lectures, Heidegger interprets phronēsis as "seeing-to" or "prudence" (Umsicht), as "insight" (Einsicht; GA 19, 21-22 / Plato's Sophist, 15-16) and as "conscience" (Gewissen; GA 19, 56 / Plato's Sophist, 39); euboulia, "proper intending-to," the most appropriate enactment of phronēsis, is interpreted as "resoluteness" (Entschlossenheit; GA 19, 150 / Plato's Sophist, 103). Hans-Georg Gadamer ("Erinnerung an Heideggers Anfänge," in Gesammelte Werke, 10: Hermeneutik im Rückblick, 7) recalls a seminar where Heidegger suddenly exclaimed on the subject of phronēsis: "Gentlemen, it's the conscience!"

On Umsicht, Gewissen and Entschlossenheit, see SZ, 69, 267-301, 305-310 / Being and Time, 98-99, 312-348, 352-358.

${ }^{42}$ See Robert Bernasconi, "The Fate of the Distinction between Praxis and Poiesis," Heidegger Studies 2 (1986): 111-139; "Heidegger's Destruction of Phronesis," The Southern Journal of Philosophy, 28/Suppl. (1989): 127-147; Walter Brogan, “A Response to Robert Bernasconi's 'Heidegger's Destruction of Phronesis'," The Southern Journal of Philosophy 28/Suppl. (1989): 149-153; "Heidegger and Aristotle: Dasein and the Question of Practical Life," in Crises in Continental Philosophy, ed. Arleen B. Dallery, Charles E. Scott, P. Holley Roberts (Albany: State University of New York Press, 1990), 137-146, 267; "The Place of Aristotle in the Development of Heidegger's Phenomenology," in Reading Heidegger from the Start: Essays in His Earliest Thought, ed. Theodore Kisiel, John van Buren (Albany: State University of New York Press, 1994), 213-227, 442-443; Hans-Georg Gadamer, "Die Marburger Theologie," in Gesammelte Werke, 3: Neuere Philosophie I: Hegel-Husserl-Heidegger (Tübingen: Mohr, 1987), 199-200 / "Martin Heidegger and Marburg Theology," in Philosophical Hermeneutics, tr. David E. Linge (Berkeley: University of California Press, 1976), 201-202; Christopher P. Long, "The ontological reappropriation of phronēsis," Continental Philosophy Review 35/1 (2002): 35-60; Jacques Taminiaux, "The Interpretation of Greek Philosophy in Heidegger's Fundamental Ontology," Journal of the British Society for Phenomenology 19/1 (1988): 3-14; "La réappropriation de l'Ethique à Nicomaque" / "The Reappropriation of the Nicomachean Ethics"; "The Interpretation of Aristotle's Notion of Aretê in Heidegger's First Courses"; John van Buren, "The Young Heidegger, Aristotle, Ethics," in Ethics and Danger: Essays on Heidegger and Continental Thought, ed. Arleen B. Dallery, Charles E. Scott, P. Holley Roberts (Albany: State University of New York Press, 1992), 169-185; Franco Volpi, Heidegger e Aristotele (Padua: Daphne, 1984), 115-116; "Dasein comme praxis: L'assimilation et la radicalisation heideggerienne de la philosophie pratique d'Aristote," in Heidegger et l'idée de la phénoménologie (Dordrecht: Kluwer, 1988), 1-41 / "Dasein as praxis: the Heideggerian assimilation and the radicalization of the practical philosophy of Aristotle," tr. Christopher Macann, in Martin Heidegger: Critical Assessments, Vol. II: History of Philosophy, ed. Christopher Macann (London: Routledge, 1992), 90-129; "La 'riabilitazione' della dynamis e dell'energeia in Heidegger."

${ }^{43}$ See GA 24, 157 / Basic Problems of Phenomenology, 111-112; GA 26, 197 / Metaphysical Foundations of Logic, 155.

${ }^{44}$ GA 22, 22; SZ, 22 / Being and Time, 43; GA 33, 31-32 / Aristotle's Metaphysics $\Theta$ 1-3, 25-26.

45 Aristotle, Physics, (Aristotle's Physics, ed. Sir David Ross (Oxford: Oxford University Press, 1936)), I.1.185a12-14 [hereafter, Phys.]. My translation. 
${ }^{46}$ Parmenides, 28.B.8.1-6, in Die Fragmente der Vorsokratiker: Griechisch und Deutsch, 3 vol., $10^{\text {th }}$ ed., ed. Hermann Diels, Walther Kranz (Berlin: Weidmannsche Buchhandlung, 1960-61).

${ }^{47}$ The refutation of Zeno's paradoxes concerning movement is carried out by Aristotle in Phys. VI.9.

${ }^{48}$ Phys. I.8.191a33-b15.

49 Plato, Sophista, in Platonis opera, Tomus I, ed. John Burnet, (Oxford: Oxford University Press, 1961), 241d5-7. My translation.

${ }^{50}$ GA 33, 160-224 / Aristotle's Metaphysics $\Theta 1-3,137-193$.

${ }^{51}$ Met. $\Theta .3 .1046 \mathrm{~b} 29-32$.

${ }^{52}$ GA 33, 179-180 / Aristotle's Metaphysics $\Theta$ 1-3, 153-154.

${ }^{53}$ Met. $\Theta .3 .1047 \mathrm{a} 14$.

${ }^{54}$ Met. $\Theta .3 .1046 \mathrm{~b} 33-1047 \mathrm{a} 4$.

${ }^{55}$ Met. $\Theta .3 \cdot 1047 \mathrm{a} 15-19,20-22$. My translation.

${ }^{56}$ Met. $\Theta .3 .1047 \mathrm{a} 4-10$.

${ }^{57}$ Sheehan interprets dynamis as "relative absentiality," "presence of the absentiality" or "pres-ab-sentiality." See Sheehan, "On Movement and the Destruction of Ontology," 536-537; "Heidegger's philosophy of mind," 289-290; “'Time and Being,' 1925-7," 30-31.

${ }^{58}$ Met. $\Theta .3 .1047 \mathrm{a} 24-26$. My translation. Cf. GA 33, 219-224 / Aristotle's Metaphysics $\Theta$ 1-3, 189-193.

${ }^{59}$ GA 33, 219 / Aristotle's Metaphysics $\Theta 1-3,188$.

${ }^{60}$ GA 33, 220-221 / Aristotle's Metaphysics $\Theta 1-3,189-190$.

${ }^{61}$ See Sheehan, "Heidegger's Topic: Excess, Recess, Access," 630; "Introduction: Heidegger, the Project and the Fulfillment," xv; "On Movement and the Destruction of Ontology"; "Heidegger's philosophy of mind"; “'Time and Being,' 1925-7," 30-31.

${ }^{62}$ Phys. III.1.201a10-11; cf. GA 18, 287-315; GA 22, 171-172, 320-321.

${ }^{63}$ WM, 242 / "On the Essence and Concept of Physis," 185.

${ }^{64}$ Phys. III.2.201b27-29, 31-33. My translation.

${ }^{65}$ In the Aristotle course of summer 1924, Heidegger comments on dynamis: "Being dynamei is a positive determination of [being] [ . . ] there [Da]. I have long been in the habit of indicating this being-character of being-there as significance [Bedeutsamkeit]. This being-character is the primary character in which the world is encountered." (GA 18, 300. My translation.) In the fragmentary notes for the course of summer 1926, Heidegger makes the following remark concerning kinessis: "Movement is a determination of the being of whatis, what-is in motion. What does movement mean ontologically? The handiness [Zuhandenheit] of what is capable of something in its capability [Bereitheit]." (GA 22, 173. My translation.)

${ }^{66}$ Thomas Sheehan, “'Time and Being,' 1925-7.".

${ }^{67}$ Heidegger specifies: "The term 'Temporality' [Temporalität] [ . . .] means temporality [Zeitlichkeit] insofar as temporality itself is made into a theme as the condition of the possibility of the understanding of being and of ontology as such.” (GA 24, 324 / Basic Problems of Phenomenology, 228.)

${ }^{68} \mathrm{GA} 22,182$. My translation.

${ }^{69}$ Aristotle, De anima, ed. W. D. Ross (Oxford: Oxford University Press, 1956), III.8.431b21. My translation.

70 PIA, 260-261 / "Phenomenological Interpretations in Connection with Aristotle," 136-137. Translation modified.

${ }^{71}$ WM, 284 / "On the Essence and Concept of Physis," 217.

${ }^{72}$ In this sense, as Heidegger points out in his 1933 rectoral address, theōria does not really take place for "its own sake" but simply "in the passion to remain close to and hard pressed by what is as such." ("Die Selbstbehauptung der deutschen Universität," in Reden und andere Zeugnisse eines Lebensweges, Gesamtausgabe, 16 (Frankfurt am Main: Klostermann, 2000), 109-110 / "The Self-Assertion of the German University," tr. Karsten Harries, Review of Metaphysics 38/3 (1985): 472.)

${ }^{73}$ Met. $\Theta .6 .1048 \mathrm{~b} 34-35$.

${ }^{74}$ Met. $\Theta .6 .1048 b 18-19,20-26$. My translation. For unknown reasons, this passage is omitted in some Greek manuscripts and is very corrupt in others; moreover, even though its general point is clear, many individual phrases are ambiguous. The passages given in <angle brackets> are emendations suggested by Hermann Bonitz. See W. D. Ross's comment, Aristotle's Metaphysics, Vol. II, 253-254.

${ }^{75}$ Met. $\Lambda .7 .1072 \mathrm{a} 24-26 ; 1072 \mathrm{~b} 14-16 ; 9.1074 \mathrm{~b} 17-18$.

${ }^{76}$ PIA, 263 / "Phenomenological Interpretations in Connection with Aristotle," 139. Translation modified. 